\title{
Molecular detection of Leishmania spp. isolated from cutaneous lesions of patients referred to Herat regional hospital, Afghanistan
}

S.H. Mosawi and A. Dalimi ${ }^{1}$

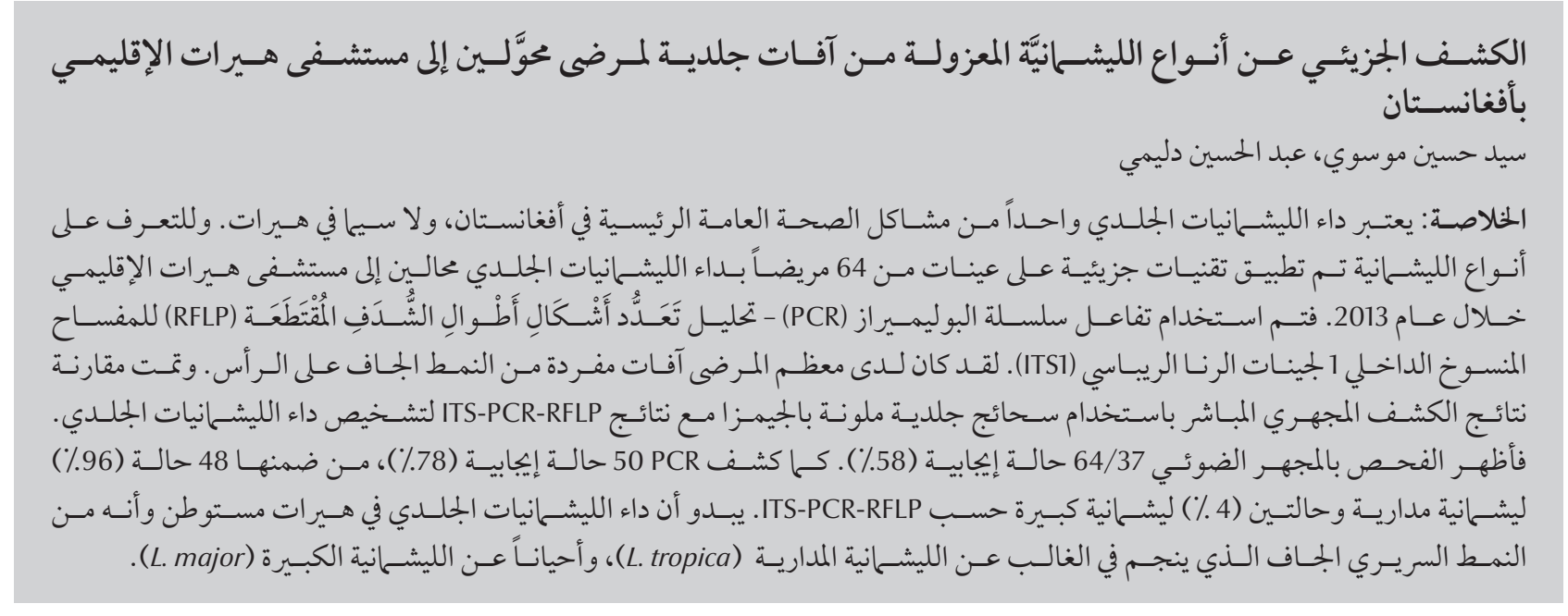

ABSTRACT Cutaneous leishmaniasis is one of the main public health problems in Afghanistan, particularly in Herat. To identify Leishmania spp., molecular techniques were applied to samples from 64 cutaneous leishmaniasis patients referred to Herat regional hospital during 2013. Polymerase chain reaction (PCR)-restriction fragment length polymorphism (RFLP) analysis of the ribosomal RNA gene internal transcribed spacer-1 (ITS1) was used. Most of the patients demonstrated dry type single lesions on the head. The results of direct microscopy detection using Giemsastained skin scrapings were compared with that of ITS PCR-RFLP for the diagnosis of cutaneous leishmaniasis. Light microscopy examination showed $37 / 64$ positive cases (58\%). PCR revealed 50 positive cases (78\%), from which ITS PCR-RFLP identified 48 cases (96\%) as L. tropica and 2 cases (4\%) as L. major. Cutaneous leishmaniasis in Herat appears to be endemic and of the clinically dry type, caused mainly by L. tropica and occasionally by L. major.

Détection moléculaire des espèces de Leishmania isolées à partir de lésions cutanées chez des patients orientés vers I'hôpital régional d'Herat (Afghanistan)

RÉSUMÉ La leishmaniose cutanée est I'un des principaux problèmes de santé publique en Afghanistan, et particulièrement à Herat. Pour identifier les espèces de Leishmania, des techniques moléculaires ont été appliquées sur des échantillons prélevés chez 64 patients atteints de leishmaniose cutanée orientés vers I'hôpital régional d'Herat en 2013. L'analyse du polymorphisme de la longueur des fragments de restriction par amplification en chaîne par polymérase de l'espaceur interne transcrit 1 au sein du gène d'ARN ribosomique (ITS PCR - RFLP) a été utilisée. La plupart des patients présentaient des lésions uniques sèches localisées sur la tête. Les résultats du dépistage microscopique direct à partir de grattages cutanés colorés au Giemsa ont été comparés à ceux de I'analyse par ITS PCR-RFLP pour le diagnostic de la leishmaniose cutanée. L'examen microscopique optique a dépisté $37 / 64$ cas positifs (58 \%). L'amplification en chaîne par polymérase a permis de dépister 50 cas positifs (78\%) ; parmi ces cas, I'analyse par ITS PCR-RFLP a identifié 48 cas (96\%) de L. tropica et 2 cas (4\%) de L. major. La leishmaniose cutanée à Herat semble endémique et de type sec au plan clinique, principalement causée par $L$. tropica et occasionnellement par $L$. major.

${ }^{\prime}$ Department of Parasitology and Entomology, Faculty of Medical Sciences, Tarbiat Modares University, Tehran, Islamic Republic of Iran (Correspondence to A. Dalimi: dalimi_a@modares.ac.ir).

Received: 09/05/15; accepted: 19/10/15 


\section{Introduction}

Leishmaniasis threatens 350 million people in 98 countries, with a global estimated incidence of 2 million cases per annum. There are 3 major manifestations of this parasitic disease: cutaneous, mucocutaneous and visceral $(1,2)$. In Afghanistan, cutaneous leishmaniasis is one of the main public health problems. While the estimated annual incidence of cutaneous leishmaniasis in Afghanistan ranges from 113100 to 226200 cases, the number of reported cases of cutaneous leishmaniasis are only 22620 annually (3).

Each Leishmania sp. has a unique epidemiological profile and therefore identification of Leishmania spp. in different regions is indispensable. Conventional methods such as microscopy and culture of amastigotes are not utilized for Leishmania spp. identification as they have an unsatisfactory level of sensitivity. Instead, DNA-based methods, such as the polymerase chain reaction-restriction fragment length polymorphism (PCR-RFLP) analysis of the internal transcribed spacer- 1 (ITS1) region of the ribosomal RNA gene (rRNA), are increasingly used for identification worldwide (4-6). DNA cards such as $\mathrm{FTA}^{\circ}$ and $\mathrm{KBC}^{\circ}$ are immediate, affordable, safe and portable tools for collection, banking and transportation of leishmaniasis samples at room temperature prior to DNA extraction, in order to carry out ecological and epidemiological studies in Afghanistan (7-9).

There is a scarcity of comprehensive data about the epidemiology of this neglected disease in Afghanistan, although there has been recent important work by Reithinger et al. (10-16). This follows earlier studies of disease foci by Eliseev and Kellina in 1962 (17) and on the epidemiology of cutaneous leishmaniasis throughout the country by Nadim et al. in the 1970s (17-20). Later, Reyburn et al. carried out a crosssectional study of a prolonged epidemic of anthroponotic cutaneous leishmaniasis during 1997-98 in Kabul (21). More recently, Faulde et al. made a molecular study of cutaneous leishmaniasis in northern parts of Afghanistan (22). Rowland et al. reported an outbreak of cutaneous leishmaniasis in an Afghan refugee camp in north-west Pakistan (23). Plourde et al. studied genetic polymorphisms and drug susceptibility of 4 isolates of Leishmania tropica acquired from Canadian soldiers returning from Afghanistan (24).

Cutaneous leishmaniasis is endemic in Herat in the west of Afghanistan and represents one of the independent foci of the disease (3). While Ahrari and Yaminhad made a 9-month demographic analysis of cutaneous leishmaniasis patients referred to Herat regional hospital (25), there is a lack of molecular data about the epidemiology of cutaneous leishmaniasis in Herat. The main aim of the present study therefore was to use molecular methods to identify Leishmania spp. isolated from cutaneous samples of patients referred to Herat regional hospital.

\section{Methods}

\section{Study design and setting}

This descriptive study was performed in Herat, a city situated in the west of Afghanistan at an altitude of $930 \mathrm{~m}$ above sea level. According to previous studies carried out in Herat, most cutaneous leishmaniasis cases are known to occur in early spring (March and April) and early fall (September and October) (25). So the study was designed to cover these periods during 2013.

\section{Sampling}

Samples were taken from 64 patients (41 males and 23 females) with clinically diagnosed cutaneous leishmaniasis who were referred to the dermatology section of the Herat regional hospital for confirmation of diagnosis (by microscopic analysis) and treatment (with pentavalent antimony).

\section{Data collection}

A questionnaire was completed which included questions about patients' demographic information and the characteristics of the lesions, and then photos of the lesions were taken and kept for future reference. Treatment was free of charge for the patients so we categorized patients' income as low if they said they would not come to hospital if treatment was not free, as intermediate if they might come to hospital if treatment was not free, and high if they would come to hospital even if treatment was not free.

Patients had not received any treatment before sample collection. Slash skin smears from the margin of lesions were also taken on DNA banking cards (for molecular analysis) and slides (for microscopic analysis).

\section{Microscopic analysis}

The slides were stained by Giemsa staining, then scanned for existing amastigotes using $\times 100$ oil-immersion light microscopy.

\section{Molecular analysis (PCR-RFLP)}

Disks (2 $\mathrm{mm}$ in diameter) were punched out from each DNA and washed 3 times with KBC DNA banking card purification buffer and twice with distilled water. The disks were air dried and put directly through PCR processing.

PCR was performed on the ITS1 region of the rRNA gene as described previously by Schönian et al. (26). Initial denaturation at $95^{\circ} \mathrm{C}$ for 5 min was followed by 35 cycles $\left(95^{\circ} \mathrm{C}\right.$ for $30 \mathrm{~s}$, $55^{\circ} \mathrm{C}$ for 30 s and $72^{\circ} \mathrm{C}$ for 45 s) and final extension for $6 \mathrm{~min}$ at $72^{\circ} \mathrm{C}$. Amplicons were detected in a $1 \%$ agarose gel holding $0.2 \mathrm{mg} / \mathrm{mL}$ ethidium bromide. Hae III was the restriction enzyme used. The PCR-RFLP products were detected in $4 \%$ agarose gel. 
The PCR product of each sample and primers were sequenced by the ABI3730XL sequence analyser (Macrogen, Korea). After editing and aligning of sequences using the ClustalW program (http://www.ebi. ac.uk/Tools/msa/clustalw2/), the sequences were compared with reference sequences from GenBank. For $L$. major and L. tropica ITS1 sequences, the phylogenetic tree was created with the neighbour-joining algorithm using Molecular Evolutionary Genetics Analysis (MEGA) software, version 6.0, including sequences of prototypical L. major and L. tropica isolates from GenBank.

\section{Geographical mapping}

The geographical locations of cases according to species of Leishmania were located using the Google Earth software. The topography of Herat was isolated from the whole topography of Afghanistan using ArcGIS geographic information system software and saved in separate files. The marginal lines contained within geomaps of Herat were indexed in the same folder. The geographical locations of cases of $L$ major and $L$. tropica were established on the final map using longitude and latitude techniques.

\section{Results}

\section{Demographic characteristics}

Out of 64 patients who were sampled for this study 41 were male (64\%) and 23 female (36\%). Although the patients' ages ranged from 1 to 85 years, the majority of patients $(67 \%)$ were aged 1-20 years. According to patients' occupation high proportion were students (45\%), and the rest were manual workers (17\%), housewives (14\%), children below school age (14\%) or in other employment (9.5\%). The patients were classified into 3 income categories, based on their ability to afford their drugs: low (56\%), intermediate (33\%) or high (11\%) (Table 1).

\begin{tabular}{|c|c|c|}
\hline Variable & No. of patients & $\%$ \\
\hline \multicolumn{3}{|l|}{ Sex } \\
\hline Male & 41 & 64 \\
\hline Female & 23 & 36 \\
\hline \multicolumn{3}{|l|}{ Age (years) } \\
\hline$<20$ & 43 & 67 \\
\hline$\geq 20$ & 21 & 33 \\
\hline \multicolumn{3}{|l|}{ Income class ${ }^{a}$} \\
\hline Low & 36 & 56 \\
\hline Intermediate & 21 & 33 \\
\hline High & 7 & 11 \\
\hline \multicolumn{3}{|l|}{ Occupational class ${ }^{b}$} \\
\hline Student & 29 & 45 \\
\hline Child & 9 & 14 \\
\hline Housewife & 9 & 14 \\
\hline Manual worker & 11 & 17 \\
\hline Other employment & 6 & 10 \\
\hline \multicolumn{3}{|l|}{ Size of lesion $(\mathrm{cm})$} \\
\hline$<1$ & 19 & 30 \\
\hline $1-2$ & 25 & 39 \\
\hline $2-3$ & 9 & 14 \\
\hline$>3$ & 11 & 17 \\
\hline \multicolumn{3}{|l|}{ Type of lesions } \\
\hline Dry & 56 & 88 \\
\hline Wet & 8 & 12 \\
\hline \multicolumn{3}{|l|}{ No. of lesions } \\
\hline 1 & 39 & 61 \\
\hline 2 & 12 & 19 \\
\hline$>2$ & 13 & 20 \\
\hline \multicolumn{3}{|l|}{ Site on body } \\
\hline Head & 26 & 41 \\
\hline Hand & 23 & 36 \\
\hline Foot & 5 & 8 \\
\hline Two or more sites & 10 & 15 \\
\hline
\end{tabular}

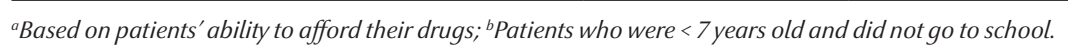

\section{Clinical profile}

Of the total patients $61 \%$ had a single lesion, 19\% had 2 lesions and 20\% had more than 2 lesions. The size of lesions varied from 0.5 to $10 \mathrm{~cm}$. A majority of cutaneous leishmaniasis lesions were on the head (41\%) or hand (36\%), and the rest were on the foot $(8 \%)$ or a combination of 2 or more sites (15\%). The majority of patients (88\%) presented with dry type lesions (Table 1).

\section{Identification and mapping of Leishmania spp.}

Among the 64 slides examined for amastigotes using light microscopy, $37(58 \%)$ were found positive and 27 (42\%) negative.

The PCR technique identified 50 positive cases out of these 64 cutaneous leishmaniasis cases (78\%). Amplified fragments of the ITS1 region of the rRNA gene on gel electrophoresis 
are shown in Figure 1, lane 4. Of these PCR-positive cases, RFLP identified 48 cases (96\%) as L. tropica and 2 cases (4\%) as L. major (Figures 1 and 2).

The phylogenetic relationships of Leishmania genotypes from Herat province were compared with other species in GenBank using the neighbour-joining algorithm (Figure 3). The sequences obtained were annotated in GenBank by accession numbers from KJ420582 to KJ420587.

The geographical distribution of cutaneous leishmaniasis cases in Herat, by species, is presented in Figure 4. The great majority of cases clustered in Injil district of Herat, with 2 cases in Zindajan and 1 case in Adraskan .

\section{Discussion}

There are many studies concerning the identification of Leishmania spp. throughout the world, especially in the Middle East and Central Asia (3). The current study was a preliminary molecular report on cutaneous leishmaniasis in Herat province. All patients were local residents of Herat. Our results revealed that anthroponotic cutaneous leishmaniasis due to L. tropica was the dominant form of leishmaniasis in Herat (48/50 PCR-positive cases), although we cannot ignore the presence of zoonotic cutaneous leishmaniasis due to L. major (2/50 cases).

Research in the Islamic Republic of Iran, which shares a border with Afghanistan, indicated that L. major was the dominant species of Leishmania (27-31), except in Mashhad province, which is located near Herat in Afghanistan, where the larger portion of Leishmania cases belongs to L. tropica (27). A study in Turkey showed that $L$. tropica was the only existing species of Leishmania in Sanliurfa province (32). A recent study also revealed that $L$. tropica was the causative agent of leishmaniasis in humans in most parts of Turkey (33). A study on leishmaniasis in Yemen
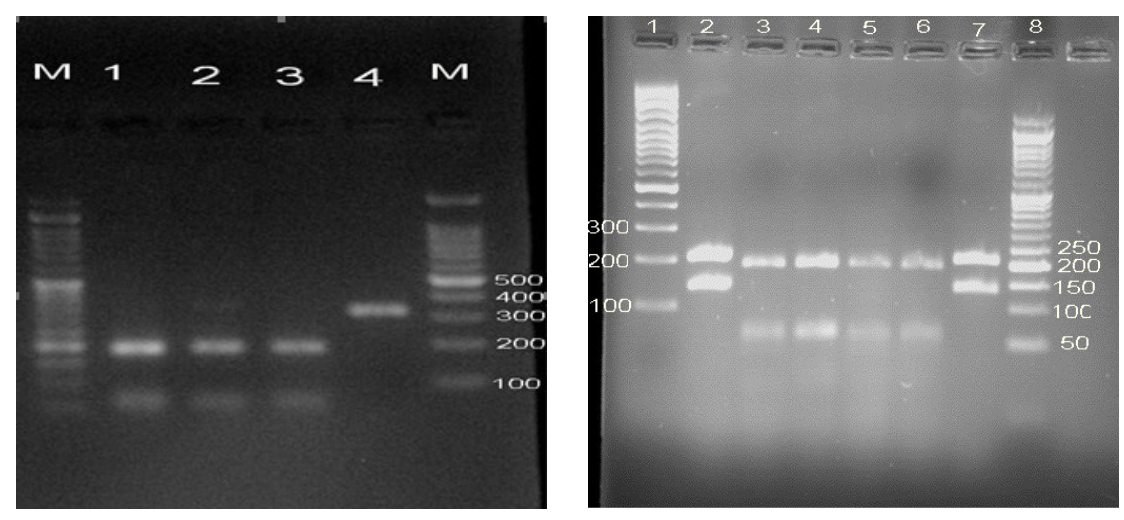

Figure 1 Polymerase chain reaction restriction-fragment length polymorphism (PCR-RFLP) analysis of the internal transcribed spacer-1 (ITS-1) region of the ribosomal RNA gene on gel electrophoresis, using the Hae III restriction enzyme. Lanes 1-3: samples recognized as Leishmania tropica; lane 4: amplified fragments of ITS1 region of rRNA gene. Left M: 50 bp marker; right M: 100 bp marker
Figure 2 Polymerase chain reaction restriction-fragment length polymorphism (PCR-RFLP) analysis of the internal transcribed spacer-1 (ITS-1) region of the ribosomal RNA gene on gel electrophoresis, using the Hae III restriction enzyme. Lane 1: $100 \mathrm{bp}$ marker, lanes 3-6: samples recognized as Leishmania tropica; lanes 2 and 7: samples recognized as L. major. Lane 8: 50 bp marker

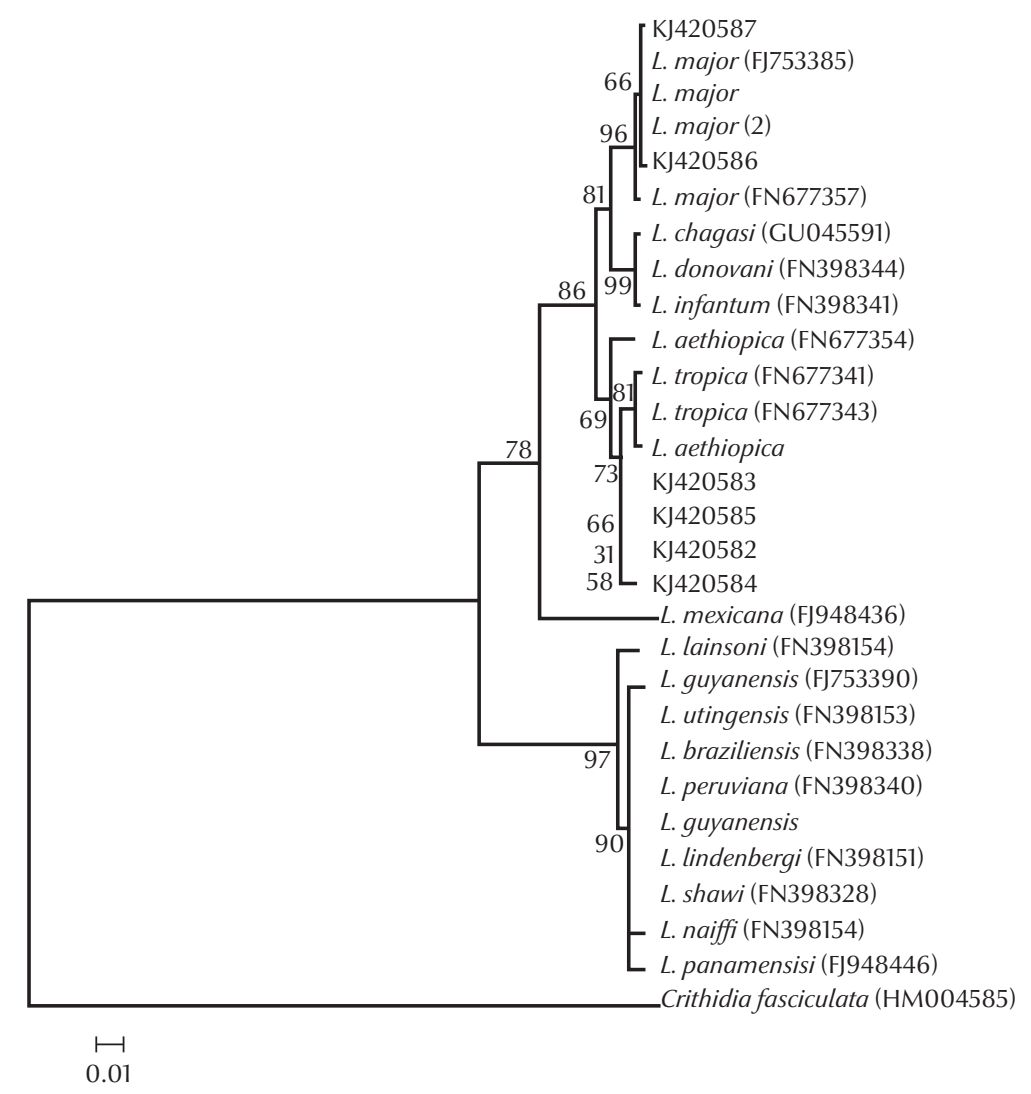

Figure 3 Phylogenetic relationships of Leishmania genotypes of the internal transcribed spacer-1 (ITS-1) region of the ribosomal RNA gene of the collected samples from Herat, Afghanistan (accession numbers KJ420582-KJ420587), compared with other species in GenBank by the neighbour-joining algorithm 
revealed that L. tropica was the paramount species of Leishmania, although L. infantum and L. donovani were also identified (34). Most studies in Pakistan indicated that L. major was the major species of Leishmania in lowland areas, while L. tropica dominated in highland areas located near Afghanistan (22).

Many studies have indicated the existence of L. major either in Central Asia or northern parts of Afghanistan. Faulde et al. in 2007 reported that zoonotic cutaneous leishmaniasis caused by L. major was endemic in Balkh province, north of Afghanistan (35). They found that of 3958 cases, 3782 (95.5\%) were zoonotic and thus concluded that L. major was the principal species of Leishmania in Balkh. In another study, the same authors found an aggressive strain of L. major in Uzbekistan (36). Moreover, according to Larréché et al. some virulent strains of L. major occur in various areas of Central Asia, especially in Turkmenistan (37).

We found that $64 \%$ of patients were male, $67 \%$ were aged under 20 years and $56 \%$ were of low income. The most

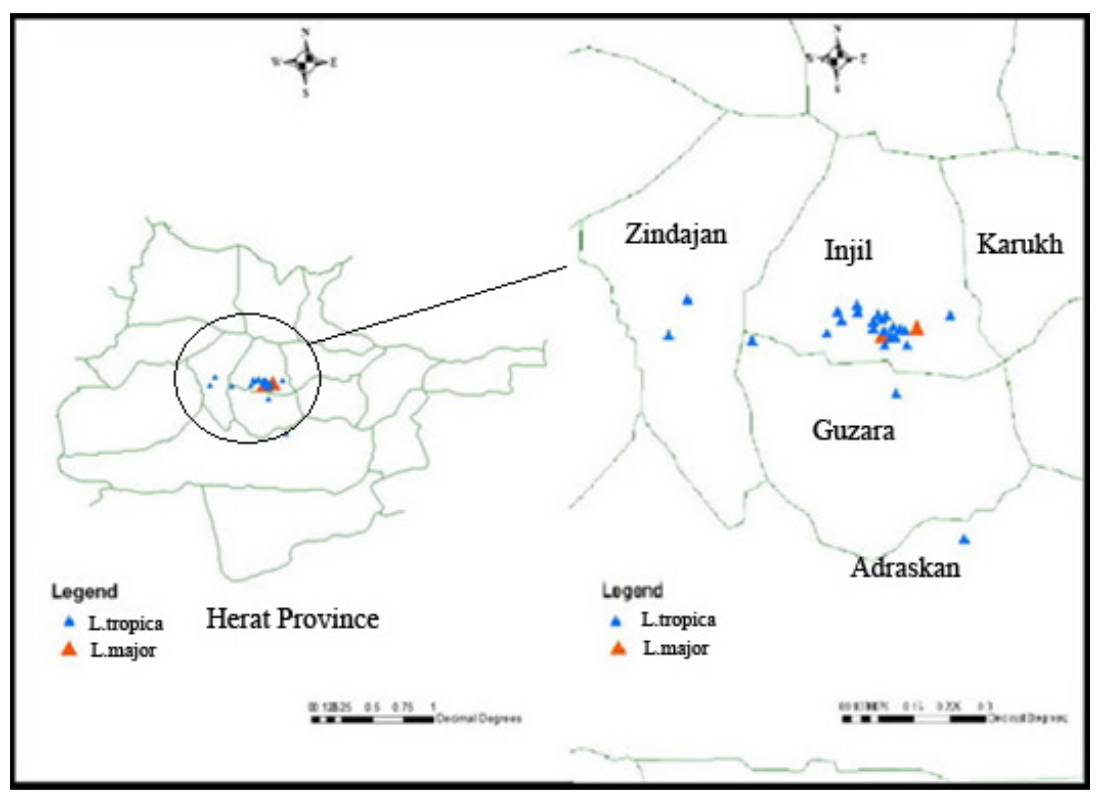

Figure 4 Geographical distribution of cases of Leishmania major $(n=2)$ and $L$. tropica $(n=48)$ from Herat in the west of Afghanistan, using ArcGIS software (left hand map shows Herat province with its districts; right hand map shows zoom view of districts) common pattern of lesions was 1 lesion (61\%), of dry type (88\%) and situated on the head (41\%). Another study conducted by Ahrari and Yamin also in Herat regional hospital produced findings roughly in line with our data (25); $48 \%$ of patients were male, a majority were under 20 years old and 83\% were of middle or lower socioeconomic class. They also found that $43 \%$ of lesions were located on the head and $60 \%$ of the patients had a single lesion. As in our study, most of their patients were resident in Injil district (25). It should be noted, however, that Injil is the nearest district to Herat hospital and it is likely that districts further from the hospital are equally affected by leishmaniasis but that patients could not afford to come to the hospital and therefore were not included in the study.

Myint et al. in their research in $\mathrm{Pa}$ kistan reported that among 69 cutaneous leishmaniasis cases, 45 (65\%) were males. Furthermore, 44 (64\%) of the patients were under 20 years old, of whom 42 (61\%) suffered from wet lesions and $46 \%$ had single lesions (22).
Their findings about the age and sex distribution of patients roughly correspond to our data. However, we found that $88 \%$ of patients had dry lesions and $61 \%$ had only a single lesion. Rassi et al. in a study in Qom, Islamic Republic of Iran, found that $46.7 \%$ of patients were males and $75.0 \%$ were aged 15 years and above. Their results about lesions showed that $64.4 \%$ of patients suffered from 1 lesion and 48.0\% of the lesions occurred on the hands (31). Kato et al. in Venezuela found that 55\% of the patients were under 20 years old, of whom $61 \%$ were males and 39\% females (8). Their results were relatively in line with our data. Khatri et al. did similar research in Yemen. His patients comprised 66\% males and 34\% females and they showed that $65 \%$ of the patients possessed single lesions and a majority of the lesion were of the dry type, 1 to $<2 \mathrm{~cm}$ in size and located on the head (34). Their findings also correspond to our data.

In conclusion, our results reveal that L. tropica was more prevalent than $L$. major in Herat province of Afghanistan. Hence, the major strategies for prevention of cutaneous leishmaniasis should be directed towards treatment of infected individuals, due to the anthroponotic nature of transmission of L. tropica. However, we should not overlook the presence of L. major in Herat province which points to zoonotic reservoirs of the disease. The existence of both L. tropica and L. major in Afghanistan calls for serious prevention strategies, treatment and vaccination. The lack of modern, sensitive equipment for diagnosis and of effective health care facilities is problematic for physicians and patients.

\section{Acknowledgements}

The authors express their gratitude to all the personnel of Herat regional hospital, especially Dr Ziaulhaq Mansoor Ahrari, deputy director of Herat Institute of 
Health Sciences, Professor Yamin, head of the dermatology section of Herat regional hospital, Dr Nadeem, manager of Herat provincial malaria and Leishmaniasis control programme, and all the personnel of Tarbiat Modares University, especially Dr Saeed Dayer, Dr Majid Pirestani, Dr Fatemeh Ghaffarifar and Dr Javid Sadraei for their kind support.
Funding: This work is part of MSc thesis in Medical Parasitology, supported financially by Tarbiat Modares University, Tehran, Islamic Republic of Iran.

Competing interests: None declared.

\section{References}

1. McGwire BS, Satoskar AR. Leishmaniasis: clinical syndromes and treatment. QJM. 2014 Jan;107(1):7-14. PMID:23744570

2. Blonski KM, Blödorn-Schlicht N, Falk TM, Faye RS, Clausen OP. Increased detection of cutaneous leishmaniasis in Norway by use of polymerase chain reaction. APMIS. 2012 Jul;120(7):5916. PMID:22716214

3. Alvar J, Vélez ID, Bern C, Herrero M, Desjeux P, Cano J, et al.; WHO Leishmaniasis Control Team. Leishmaniasis worldwide and global estimates of its incidence. PLoS One. 2012;7(5):e35671. PMID:22693548

4. Tomás-Pérez M, Fisa R, Riera C. The use of fluorescent fragment length analysis (PCR-FFL) in the direct diagnosis and identification of cutaneous Leishmania species. Am J Trop Med Hyg. 2013 Mar;88(3):586-91. PMID:23382161

5. Gadisa E, Genetu A, Kuru T, Jirata D, Dagne K, Aseffa A, et al. Leishmania (Kinetoplastida): species typing with isoenzyme and PCR-RFLP from cutaneous leishmaniasis patients in Ethiopia. Exp Parasitol. 2007 Apr;115(4):339-43. PMID:17083934

6. Schönian G, Kuhls K, Mauricio IL. Molecular approaches for a better understanding of the epidemiology and population genetics of Leishmania. Parasitology. 2011 Apr;138(4):405-25. PMID:21078222

7. Kato H, Cáceres AG, Mimori T, Ishimaru Y, Sayed AS, Fujita M, et al. Use of FTA cards for direct sampling of patients' lesions in the ecological study of cutaneous leishmaniasis. J Clin Microbiol. 2010 Oct;48(10):3661-5. PMID:20720027

8. Kato H, Watanabe J, Mendoza Nieto I, Korenaga M, Hashiguchi Y. Leishmania species identification using FTA card sampling directly from patients' cutaneous lesions in the state of Lara, Venezuela. Trans R Soc Trop Med Hyg. 2011 Oct;105(10):561-7. PMID:21907375

9. Fata A, Khamesipour A, Mohajery M, Hosseininejad Z, Afzalaghaei M, Berenji F, et al. Whatman paper (FTA cards) for storing and transferring Leishmania DNA for PCR examination. Iran J Parasitol. 2009;4(4):37-42.

10. Reithinger R, Aadil K, Hami S, Kolaczinski J. Cutaneous leishmaniasis, northern Afghanistan. Emerg Infect Dis. 2004 May;10(5):966-7. PMID:15216854

11. Reithinger R, Aadil K, Kolaczinski J, Mohsen M, Hami S. Social impact of leishmaniasis, Afghanistan. Emerg Infect Dis. 2005 Apr;11(4):634-6. PMID:15834984

12. Reithinger R, Coleman PG. Treating cutaneous leishmaniasis patients in Kabul, Afghanistan: cost-effectiveness of an operational program in a complex emergency setting. BMC Infect Dis. 2007;7(1):3. PMID:17263879

13. Reithinger R, Dujardin J-C, Louzir H, Pirmez C, Alexander B, Brooker S. Cutaneous leishmaniasis. Lancet Infect Dis. 2007 Sep;7(9):581-96. PMID:17714672

14. Reithinger R, Mohsen M, Aadil K, Sidiqi M, Erasmus P, Coleman PG. Anthroponotic cutaneous leishmaniasis, Kabul, Afghanistan. Emerg Infect Dis. 2003 Jun;9(6):727-9. PMID:12781016

15. Reithinger R, Mohsen M, Leslie T. Risk factors for anthroponotic cutaneous leishmaniasis at the household level in Kabul, Afghanistan. PLoS Negl Trop Dis. 2010;4(3):e639. PMID:20351787
16. Reithinger R, Mohsen M, Wahid M, Bismullah M, Quinnell RJ, Davies CR, et al. Efficacy of thermotherapy to treat cutaneous leishmaniasis caused by Leishmania tropica in Kabul, Afghanistan: a randomized, controlled trial. Clin Infect Dis. $2005 \mathrm{Apr}$ 15;40(8):1148-55. PMID:15791515

17. Eliseev LN, Kellina OI. Cutaneous leishmaniasis in Afghanistan. Med Parazitol (Mosk). 1963 Nov-Dec;32:728-35 [in Russlan]. PMID:14159831

18. Nadim A, Javadian E, Noushin MK, Nayil AK. Epidemiology of cutaneous leishmaniasis in Afghanistan. Part I: Zoonotic cutaneous leishmaniasis. Bull Soc Pathol Exot Filiales. 1979 Jan-Feb;72(1):31-5. PMID:498385

19. Nadim A, Javadian E, Noushin MK, Nayil AK. Epidemiology of cutaneous leishmaniasis in Afghanistan. Part 2. Anthroponotic cutaneous leishmaniasis. Bull Soc Pathol Exot Filiales. 1979 Sep-Dec;72(5-6):461-6. PMID:261933

20. Nadim A, Rostami GS. Epidemiology of cutaneous leishmaniasis in Kabul, Afghanistan. Bull World Health Organ. 1974;51(1):45-9. PMID:4549041

21. Reyburn H, Rowland M, Mohsen M, Khan B, Davies C. The prolonged epidemic of anthroponotic cutaneous leishmaniasis in Kabul, Afghanistan: 'bringing down the neighbourhood'. Trans R Soc Trop Med Hyg. 2003 Mar-Apr;97(2):170-6. PMID:14584372

22. Myint CK, Asato Y, Yamamoto Y, Kato H, Bhutto AM, Soomro FR, et al. Polymorphisms of cytochrome b gene in Leishmania parasites and their relation to types of cutaneous leishmaniasis lesions in Pakistan. J Dermatol. 2008 Feb;35(2):76-85. PMID:18271802

23. Rowland M, Munir A, Durrani N, Noyes H, Reyburn H. An outbreak of cutaneous leishmaniasis in an Afghan refugee settlement in north-west Pakistan. Trans R Soc Trop Med Hyg. 1999 Mar-Apr;93(2):133-6. PMID:10450434

24. Plourde M, Coelho A, Keynan Y, Larios OE, Ndao M, Ruest A, et al. Genetic polymorphisms and drug susceptibility in four isolates of Leishmania tropica obtained from Canadian soldiers returning from Afghanistan. PLoS Negl Trop Dis. 2012 Jan;6(1):e1463. PMID:22272366

25. Ahrari Z, Yamin N. Cutaneous leishmaniasis in Herat (dissertation). Herat: University of Herat; 2010 [in Dari Farsi].

26. Schönian G, Nasereddin A, Dinse N, Schweynoch C, Schallig HD, Presber W, et al. PCR diagnosis and characterization of Leishmania in local and imported clinical samples. Diagn Microbiol Infect Dis. 2003 Sep;47(1):349-58. PMID:12967749

27. Vaeznia H, Dalimi A, Sadraei J, Pirstani M. Determination of Leishmania spp. causing cutaneous leishmaniasis in Mashhad by PCR-RFLP method. Archives of Razi. 2009;64(1):39-44.

28. Akhoundi M, Hajjaran H, Baghaei A, Mohebali M. Geographical distribution of Leishmania species of human cutaneous leishmaniasis in Fars province, southern Iran. Iran J Parasitol. 2013 Jan;8(1):85-91. PMID:23682265

29. Khosravi A, Sharifi I, Dortaj E, Aghaei Afshar A, Mostafavi M. The present status of cutaneous leishmaniasis in a recently emerged focus in south-west of Kerman province, Iran. Iran J Public Health. 2013;42(2):182-7. PMID:23515397 
30. Mirzaie F, Eslami G, Yosefi MH, Pestehchian N. Molecular identification of Leishmania isolates obtained from patients suspected as having cutaneous leishmaniasis referred to reference laboratories from Yazd province in central Iran. Adv Biomed Res. 2013;2:92. PMID:24524036

31. Rassi Y, Saghafipour A, Abai MR, Oshaghi MA, Mohebali M, Mostafavi R. Determination of Leishmania parasite species of cutaneous leishmaniasis using PCR method in Central County, Qom Province. Zahedan Journal of Research in Medical Sciences. 2013;15(12):13-6.

32. Akkafa F, Dilmec F, Alpua Z. Identification of Leishmania parasites in clinical samples obtained from cutaneous leishmaniasis patients using PCR-RFLP technique in endemic region, Sanliurfa province, in Turkey. Parasitol Res. 2008 Aug;103(3):583-6. PMID:18509680

33. Toz SO, Culha G, Zeyrek FY, Ertabaklar H, Alkan MZ, Vardarlı AT, et al. A real-time ITS1-PCR based method in the diagnosis and species identification of Leishmania parasite from human and dog clinical samples in Turkey. PLoS Negl Trop Dis. 2013;7(5):e2205. PMID:23675543
34. Khatri ML, Di Muccio T, Gramiccia M. Cutaneous leishmaniasis in North-Western Yemen: a clinicoepidemiologic study and Leishmania species identification by polymerase chain reaction-restriction fragment length polymorphism analysis. J Am Acad Dermatol. 2009 Oct;61(4):e15-21. PMID:19695737

35. Faulde M, Schrader J, Heyl G, Amirih M, Hoerauf A. Zoonotic cutaneous leishmaniasis outbreak in Mazar-e Sharif, northern Afghanistan: an epidemiological evaluation. Int J Med Microbiol. 2008 Jul;298(5-6):543-50. PMID:17888728

36. Faulde MK, Werner A, Heyl G. Untreated zoonotic cutaneous leishmaniasis characterizing a highly aggressive strain type of Leishmania major in Uzbekistan. J Eur Acad Dermatol Venereol. 2007 Nov;21(10):1432-3. PMID:17958865

37. Larréché S, Launay G, Weibel Galluzzo C, Bousquet A, Eperon G, Pilo JE, et al. Cluster of zoonotic cutaneous leishmaniasis (Leishmania major) in European travelers returning from Turkmenistan. J Travel Med. 2013 Nov-Dec;20(6):400-2. PMID:24165385 